\title{
Türkiye'de 2000 Sonrası El Halısı Üretimi ve Ticareti
}

\author{
Hand Woven Carpet Manufacture and Trade in Turkey After 2000 \\ Bahadır Öztürk, Geleneksel Türk Sanatları Bölümü, Dokuz Eylül Üniversitesi
}

\begin{abstract}
Özet
Türkiye'de halıcılık sektörü, 1990 sonrası makine halıcılığının da gelișmeye bașlamasıyla, insan emeğine dayalı el halıcılığı ile sermayeye dayalı makine halıcılığı alanlarında iki farklı kulvarda üretim ve ticaret yaparak iç ve diş piyasa taleplerini karşılamaya çalışmıştır. 2000'ler ile el halıcığı alanında, üretim ve rekabet koşullarının değișmesi geçimini bu ișten sağlayan bazı yerli üretici ve tüccarı, gelirlerinin daha fazla düşmemesi, olanın kaybedilmemesi, kazanç ve karlılığın arttırılması için halı ithal etmeye yönlendirmiștir. Üreticiler ya üretimlerini Uzak Doğuya kaydırmış ya da buralardan siparișle halı yaptırarak bir süre için yüksek miktarda ticaret yapmışlardır. Bunda dünya ekonomisinin küreselleşmesi ve Uzak Doğudakiler gibi işçilik maliyetlerinin düşük olduğu ülkelerde gelişen fason üretim şekli etkili olmuştur. Bu süreçte yerel el üretimi halıcllık günümüze geldikçe, her geçen yıl hızla azalarak bitme noktasına gelmiştir. El halıcılığının en önemli sorunu malzeme ve işçilik maliyetleridir. Bunula birlikte el halısı sektörü eski el dokuması halıların yeniden değerlendirilmesi kapsamında ihracatı geliștirici ve istihdam sağlayıcı yeni yollar geliştirse de el halıcılığının son durumu yirmi yll öncesine göre çok kötüdür.
\end{abstract}

Bu makalede, Türkiye'de el halıcılığının 2000 yılından günümüze yaşadığı gelişmeler, sorunlar ve sektörün geleceğine dair beklentiler ele alınmıștır. Bunun için, kalkınma planları, ticari veriler, sektörel yayınlar, toplantılar, Trademap'den ve sektör temsilcilerinden alınan güncel bilgilerden yararlanılmıștır. Türkiye'nin el halıcılığının yakın tarihine dair literatürde yöresel anlamda çalışmalar olmakla birlikte, bu çalışmanın genele bakan bir akademik çalışma olması, güncel bilgiler içermesi, sektörel önerilere yer vermesi açısından önemli olduğu düşünülmektedir.

Anahtar Sözcükler: Türk el halıcılığı, halı ithalatı, halı ticareti, ticari veriler.

Akademik disipin(ler)/alan(lar): Geleneksel Türk Sanatları, Halı Kilim ve Geleneksel Kumaş Desenleri. \begin{abstract}
The carpet industry in Turkey has tried to meet the domestic and foreign market demands by producing and trading in two fields of hand-made carpets based on manual labor and machine-made carpets based on capital. The change in the production and competition conditions in the field of hand-made carpets in the 2000s led some local producers and traders to import carpets in order not to decrease their income, not to lose the existing revenue, and to increase profit and profitability. Manufacturers either shifted their production to the Far East, or produced carpets upon orders from these places??? and continued to make high amounts of trade for a period of time. The globalization of the world economy and the developing contract manufacturing method in countries where labor costs are low, such as those in the Far East, have been effective in this. In this process, the local hand-made carpet production has recently also come to an end point decreasing rapidly each year. The most important problems of hand-woven carpets are the costs of material and labor. However, although the hand-made carpet industry has developed new ways to improve exports and provide employment within the scope of reevaluating old hand-woven carpets, the current situation of handmade carpets is much worse than it was twenty years ago.
\end{abstract}

In this article, the developments, problems, and expectations about the future of the hand-made carpet sector in Turkey since 2000 are discussed. For this, development plans, commercial data, sectoral publications, meetings, up-to-date information from Trademap, and sector representatives were used. Although there are surveys in the literature on the recent history of Turkey's local hand-made carpets, it is thought that this study is important in terms of being a general academic study, containing up-to-date information and giving place to sectoral recommendations.

Keywords: Turkish hand woven carpet manufacture, Carpet import, carpet trade, trade data.

Academical disciplines/fields: Traditional Turkish Arts, Carpet Rug and Traditional Fabric Patterns.

- $\quad$ Sorumlu Yazar: Bahadır Öztürk, Geleneksel Türk Sanatları Bölümü, Güzel Sanatlar Fakültesi, Dokuz Eylül Üniversitesi.

- $\quad$ Adres: Dokuz Eylül Üniversitesi Güzel Sanatlar Fakültesi, DEÜ Tınaztepe Yerleşkesi, Adatepe Mah. Doğuş Cad. No: 209,35390 Buca - İzmir.

- e-posta: bahadir.ozturk@deu.edu.tr

- ORCID: 0000-0001-8492-3459

- Çevrimiçi yayın tarihi: 10.01 .2022

- doi: $10.17484 /$ yedi.1031506 


\section{Giriș}

2000'den önce el halısı üretimi devlet tarafından önemli bir üretim ve kültürel bir değer olarak görülmüș, desteklenmiștir. Bu durum devletin hazırlattığı kalkınma planlarından anlaşılabilmektedir. Burada el halıcılığının hala iç tüketim için önemli bir ihtiyaç, ülke ekonomisi, ihracat için katma değerli bir ürün ve istihdam yaratıcı bir üretim olması etkili olmaktadır. 1980’lerden itibaren el halıcılığına olan devlet desteği, ilgi ve yatırım da artmış, kooperatifçilik, atölye üretiminde ve üretilen halı kalitesinde de gelişme görülmektedir. Türkiye 1990'ların ortasına kadar el halısında yalnızca ihracatçı bir ülke iken, Gümrük birliği ile 1996'dan itibaren el halısı ithalatı yaptığı da görülmeye başlanmıștır. Bu yıllarda el halıcılığı için üretimin olduğu ve her geçen yıl dokuyucu sayıları ile üretimin düştüğünden bahsedilmektedir. Türkiye'de el halıcılığının düşme sebeplerinden bazıları, köyden kente göçün artması, köylerde dokuyucu sayılarının düşmesi, zorunlu ilköğretim, ekonominin ve eğitim seviyesinin artması, çalışanların düzenli gelir, emeklilik ve sosyal haklar talep etmeleri ve bu bilincin artması; bu isteklere paralel olarak işçilik ve malzeme fiyatlarının yükselmesi gösterilmektedir. Tüm bunlarla beraber Türkiye'de özellikle iç piyasa için üretim yapan yerli el halısı üreticisini hızla gelişen makine halıcılığı bitirmiştir. Makine halısı sektörü iç tüketim taleplerinin neredeyse tamamını karşılarken, ihracat da yapmaya başlamıştır (Öztürk, 2021).

Türkiye'de el halıcılığının son yirmi yılının ele alındığı bu çalışmada yer alan veriler, kalkınma planları, sektörel yayınlar, toplantılar, Trademap ve sektör temsilcilerinden gelen güncel bilgilerden alınmıştır. Makale Türkiye'nin yakın tarihine dair güncel bilgilere yer verirken, el halısı sektörü hakkında kronolojik olarak toparlayıcı bir tarih çizmeye çalışılmakta ve sektörel önerilere yer vermektedir.

\section{El Halısı Üretimi ve Ticareti (2000-2020)}

2001 yılı verilerine göre Türkiye'nin 30 milyon $\mathrm{m}^{2}$ el halısı üretiminin olduğu, 1,5 milyon kişinin bu işle meşgul olduğu ve 2 milyar dolar cirosunun bulunduğu, bu rakamın 400-450 milyon dolarlık kısmının iç tüketim, 350-400 milyon dolarlık kısmının direkt ihracat, 1.150 milyon dolarlık kısmının ise turistik satışlardan geldiği söylenmektedir. Türkiye'nin dünya ihracatındaki payı \%5'tir. İran \%40, Hindistan \%17, Pakistan \%16 pay almaktadır (Devlet Planlama Teşkilatı [DPT], 2001, s. 76-77). Bu rakamlara bakıldığında 2001 yılı için Türkiye'nin oldukça iyi bir üretim ve ihracatının olduğu görülmektedir. Aynı yıl için Trademap verilerinde ise Türkiye 98 milyon dolar ihracat yapmıştır ve buna karşı 33 milyon dolar da el halısı ihracatı gerçekleștirilmiştir. Trademap verilerine yalnızca gümrük bilgilerinin işlendiği, turistlere direkt satışların ve kayıt dışı ihracatın ise dahil edilmediğini belirtmek gerekir. Yine de veriler arasında oldukça yüksek bir uçurum vardır.

2008 yılında yayınlanan Türkiye El Halıcılığı Sektör Araştırmasında Dünyada el halıcılığının durumu, üretici ve ithalatçı ülkeler, bunların pazar payları, geleceğe yönelik piyasa öngörüleri üzerine durularak, Türkiye'nin bu pazardaki yeri konusunda değerlendirmeler yapılmıştır. Bu yıllarda el halıcılı̆̆ tezgâh halıcılığı olarak en fazla Batı ve Orta Anadolu'da yapılmakla birlikte ucuz iş gücü nedeniyle üretimin Doğu illerine kaydığı görülmektedir. Üretim yurda yayılmış birçok ilde de şahıs, küçük ve büyük işletme, kooperatif, kamuda 11 bakanlık ve Sümer Halı tarafından gerçekleştirilmektedir (Bilgin ve Demir, 2008, s. 75).

El dokuması Halı ve kilim üretiminin yaygın olduğu yerler: Orta Anadolu'da Konya, Sivas, Kayseri yöresinde Karapınar, Taşpınar, Lâdik, Sarayönü, Bünyan, Yahyalı, Mucur, Şarkıșla, Eskișehir, Sivrihisar, Niğde; Batı Anadolu yöresinde Isparta, Bergama, Balıkesir, Çanakkale, Ezine, Yağcıbedir, Demirci, Uşak, Kula, Gördes, Milas, Kocaeli- Hereke; Güney Anadolu'da, Fethiye, Döșemealtı; Doğu ve Güneydoğu Anadolu'da Malatya, Kars, Erzurum, Van, Bitlis ve Siirt'tir (Bilgin ve Demir, 2008, s.75). Bu yıllarda el halıcılığında görülen sorunlar;

- El halıcllğı ile ilgili birçok kamu kuruluşunun çalışma yapması, ancak yapılan çalışmaların birbirinden bağımsız olması, koordinasyon bulunmaması nedeniyle istenilen sonuca ulaşlamaması,

- Yașı küçük veya nitelikli olmayan dokumacı çalıștırılması, sosyal güvencenin verilememesi, gerekli eğitim desteğinin sağlanmaması, çalışma koşullarının sağlıklı olmaması, ulaşım ve yemek ihtiyaçlarının karşılanmaması nedeniyle dokumacıların her geçen gün azalması ve sektöre olan ilginin düşmesi,

- 1980 yılında yürürlüğe giren, nüfusu 5000'in altındaki yerleșim yerlerinde üretim yapan halı, kilim imal eden işletmelerde çalışan işçilerin vergiden muaf tutulması hükmünün, nüfus artışı nedeniyle işletilememesi, 
- Üretimin uzun olması nedeniyle üreticinin finansman sıkıntısı çekmesi,

- Türk el halısının tanıtımının yurt dışında iyi yapılmaması,

- İhraç edilen Türk el halılarının gerekli standartları sağlamaması nedeniyle, pazarda değer kaybetmesi,

- En önemlisi de yurtdışından ucuza ithal edilen el halılarının fiyat rekabeti nedeniyle yerli el halıclığına zarar vermesidir (DPT, 2001, s.188).

Türkiye'de el halıclığı alanında ithalatın ve ithalata dayalı ihracatın önünü 1996 yılında tam üyelikle girilen Gümrük birliği mevzuatı açmıştır denilebilir. Türkiye Gümrük birliği ile Dünyaya açılmış, entegrasyon çalışmalarıyla sosyal ve ekonomik anlamda birçok kazanımlar elde etmiştir (Güner ve Aytekin, 2016, s. 5152). Küreselleşme ile bazı sektörler için Türkiye Avrupa'nın üretim ve tedarik merkezlerinden birine dönüșürken, Uzak Doğu'da fason üretimle birlikte el halıcllı̆̆ının gelișmesi ve Türkiye'den çok daha ucuza gelen malzeme ve işçilik maliyetleri, yerli el halısı sektörünün karşısına hem tehdit hem de firsat olarak çıkmıştır. Bu bağlamda 2000'ler Türkiye'deki el halıcılı̆̆ı için önemli kararların alındığı veya alınmak zorunda kalındığı yıllardır. Türk halıcılığı artık Çin, Hindistan, Pakistan, Nepal gibi uzak doğu ülkelerinin ucuz iş gücü ve malzeme maliyetleri ile rekabet edememektedir. Birçok yerli üretici üretimlerini Uzak Doğuya kaydırmış veya buralardan ithalata yönelmiștir (Bilgin ve Demir, 2008, s. 86).

El halılarını yurtdışından ucuza getirenler, halıları yerli üreticiden çok daha ucuza satmaktadır bu da yerli halıclığa ve ticaretine darbe vurmaktadır. Halı ticareti ve üretimi ile uğraşanlar ikiye bölünmüş̧ durumdadır. Yurt dışından ucuza gelen halılar bir taraftan turistlere ve ihracata giderken ülkeye döviz girmekte; diğer taraftan yerli üretici yüksek maliyetler nedeniyle ürettiği malı satamadığı için el halılarındaki ithalatın engellenmesi veya azaltılması için tedbir alınmasını istemektedir (Bilgin ve Demir, 2008, s. 94). El halıcılı̆ıının her geçen yıl azaldığından ve bitme noktasına geldiğinden söz edilmektedir (Bilgin ve Demir, 2008, s.83). Yurtiçi tüketici taleplerine bakıldığında ise tüketiciler yüksek fiyatlı yerli el halıları yerine makine halılarını veya modern tasarımlı ucuz Uzakdoğu üretimlerini tercih etmektedir (Bilgin ve Demir, 2008, s. 85).

Uzak Doğu ülkelerinin bu işlere girişmesi ise 1980'lerden sonra, dünya küreselleşmeye ve siyasi birliktelikler yerini ekonomik birlikteliklere bıraktığı zamanlarda başlamıştır. Uzak Doğu ülkelerinin dış pazarlara dahil olması ve sahip oldukları insan gücünü hizmete açması ile başlayan fason üretim, ilk bașta bu ülkelerin siyasi, ekonomik ve adli sistemleri nedeniyle risk olarak görünse de dünyanın her yerinden bu riske giren ve çok büyük karlar elde eden girişimciler diğer girişimcilere örnek olmuştur. Birçok alandan şirket ya üretimlerini buralara taşımış ya da siparişle ürün yaptırma yoluna gitmiştir. Yoğun insan gücüne dayalı el halıcılığı da bu sektörlerden birisidir ve Uzak Doğu ülkeleri el halıcılığını kısa sürede öğrenip insan gücü ile hammadde maliyeti avantajını kullanarak 2000 'ler ile üretim ve ihracatta dünya piyasasında en büyük paya sahip olmuşlardır.

2001- 2010 yılları arasında Türkiye'nin el halısı ithalatına bakıldığında (Bkz. Şekil 1), 2003 yılında 35 milyon dolar iken 2008 yılında 122 milyon dolara yükselen bir grafik şeklinde çıkmaktadır. Bu yıllar arası en çok el halısı alınan ülkeler sırasıyla Çin, Hindistan ve Pakistan'dır. Tabloda 2008 yılından 2009'a Amerika'da başlayıp dünyaya yayılan ekonomik kriz nedeniyle ithalatta aşağı yönlü ciddi bir düşüş yaşanmış ve toplam ithalat 89 milyon dolar olmuş, ardından tekrar yükselişe geçmiștir. 2010 yllında ithalat 111 milyon dolara ulaşmıştır. 2009 yılından sonra Hindistan Çin'in önüne geçmiş Türkiye'nin en fazla el halısı ithal ettiği ülke olmuştur.

2010 yılında bir haberde, İHİB Bașkanı İbrahim Yılmaz’ı "El halısı ithalatı serbest bırakılırsa, ihracatı 1 milyar doları aşar, 100 bin kişiye iş sağlanır. Türkiye'de el halısı üretimi yok denecek kadar azaldı. Bu ekonomik gelişmenin sonucu. Eğer el halısı ve eski halı ithalatını serbest bırakırsak, Afganistan, Pakistan ve İran eksenindeki el halısı ticareti İstanbul'a döner ve bizim sadece el halısı ihracatımız çok kısa sürede 1 milyar doları aşar." şeklinde bir demecinin olduğu söylenmektedir (Güngör, 2010).

2001-2010 yılları arası Türkiye'nin el halısı ihracatına bakıldığında 2001-2003 arasında el halısı ihracatında 98 milyon dolardan 71 milyona düșüş gözlenmektedir. 2008'e kadar aynı yıllara ait el halısı ithalatı grafiğindeki gibi yükselen bir artış vardır. 2007'de grafiğin en yüksek değeri olan 132 milyon dolar ihracat yapılmıştır. Yine kriz nedeniyle 2008-2009 arasında bir düşüş gözlenmektedir. 2009'da ihracat 115 milyon dolar olmuştur. 2001-2009 arasında Türkiye'nin en yüksek ihracat yaptığı yerin Serbest Bölge olduğu görülmektedir. 2005 yılında İstanbul Atatürk Havalimanı ve Kocaeli Serbest Bölgelerinden yapılan ihracat, toplam el halısı ihracatının \%52'sini oluştururken bu oran 2007 yllında \%45'e düşmüștür (Bilgin ve Demir, 2010, s. 89). Serbest bölgelerin ardından ABD, Japonya, İtalya, Fransa, İspanya gelmektedir. 
2009'dan sonra 2010'da serbest bölge ihracatı birden düşerken, diğer bazı ülkeleri de kapsayacak şekilde, bir miktar artış vardır ve değer 133 milyon dolarla kriz öncesi seviyeyi aşmaktadır (Şekil 2).

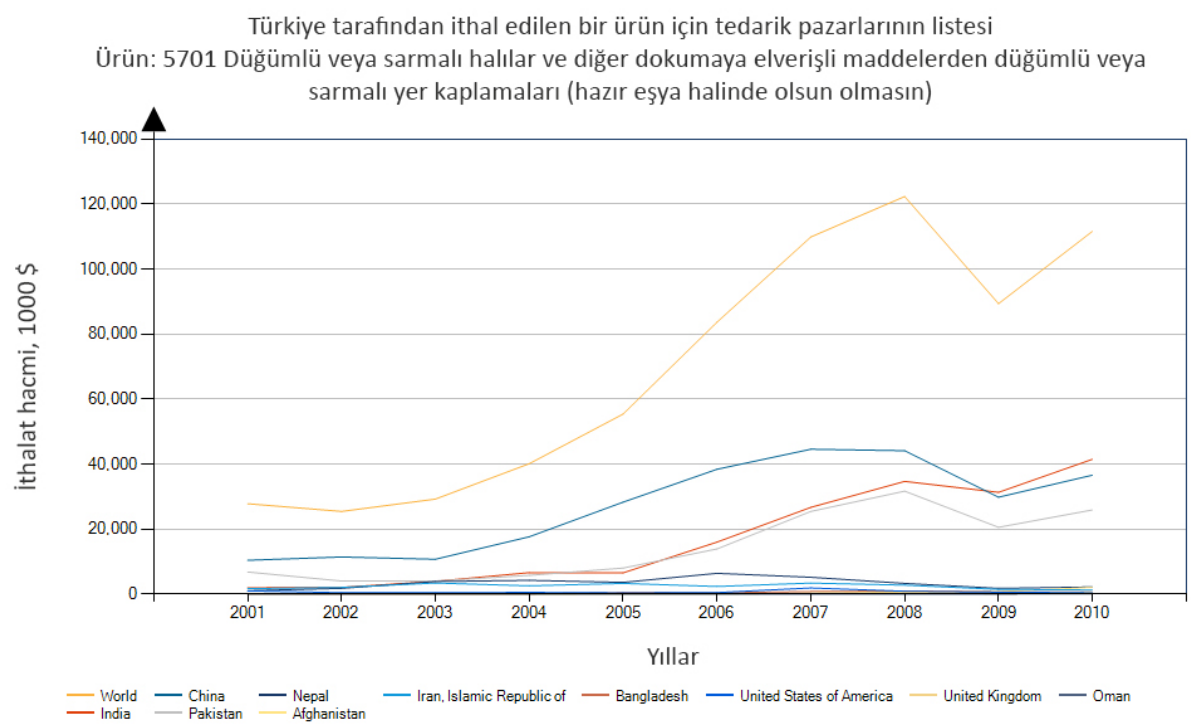

Şekil 1. Türkiye'nin 2001- 2010 arası el halısı ithalatı (www.trademap.org)

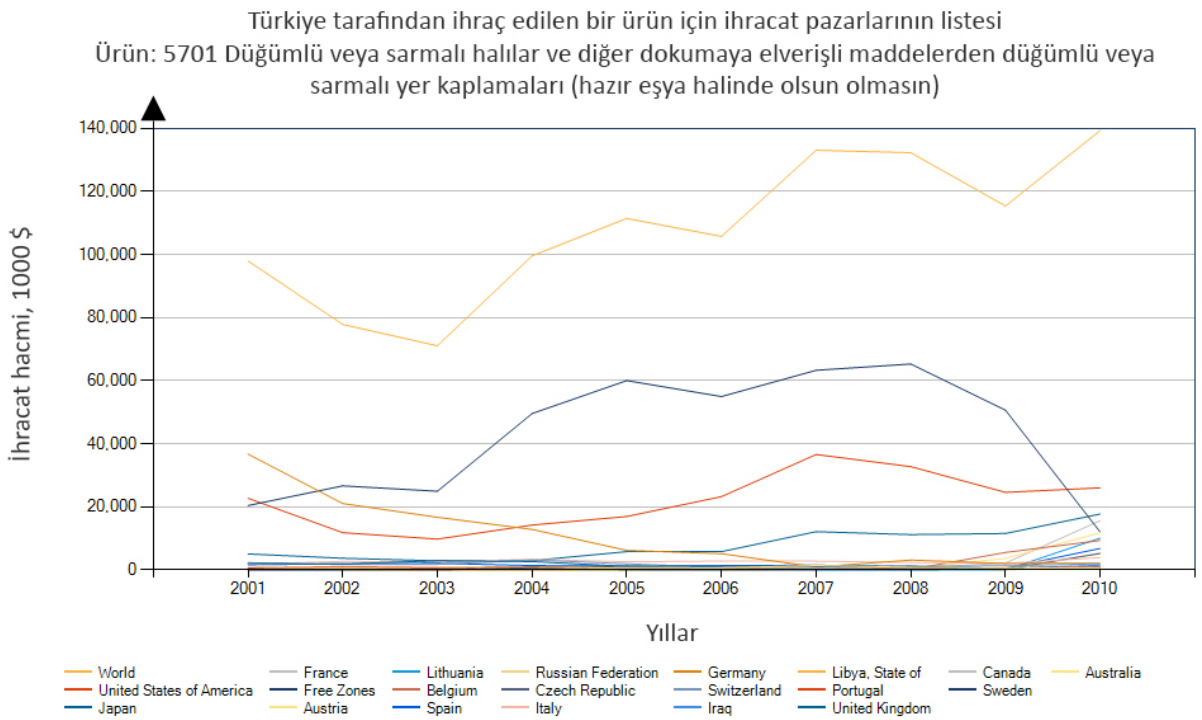

Şekil 2. Türkiye'nin 2001- 2010 arası el halısı ihracatı (www.trademap.org).

Bu dönemde yerli üretici ile halı üretimine el sanatı ve kültürel bir değer olarak bakanlar, bu üretimin yok olmaması için halıcılığa önem verilmesi, desteklenmesi ve teşvik edilmesi gerektiğini ifade etmektedirler. Yerli üreticilere eleştirel bakanlar ise onların geçmişe dönük olarak kendilerini hiç geliştirmedikleri, piyasayı takip etmedikleri, tasarım ve renge önem vermediklerini dile getirmekte; Yerli halıcılığın, yüksek getirili, kaliteli, modaya uygun, butik ürünler üreterek ayakta kalabileceğini söylemektedirler (Bilgin ve Demir, 2008, s. 86).

Kamuda halı sektörüne öncülük eden Sümerhalı veya diğer adıyla Sümer Halıcılık El Sanatları ve Ticaret AŞ.'de de durum farklı değildir. Devlet desteği ile Uzak Doğu malları ile rekabet etmeye çalışan şirketin 2002 yılında $35.542 \mathrm{~m}^{2}$ olan el halısı satışı 2003 yılında $16.398 \mathrm{~m}^{2}$ ye inmiş, 2004 yılında yapılan tanıtım faaliyetlerinin etkisi ile $62.350 \mathrm{~m}^{2}$ 'ye yükselmiş, 2005 yılında $28.433 \mathrm{~m}^{2}$, 2006 yılında $19.165 \mathrm{~m}^{2}, 2007$ yılında $13.075 \mathrm{~m}^{2}, 2008$ yılında ise $8.668 \mathrm{~m}^{2}$ olarak gerçekleştirmiştir ve yılı yaklaşık 6,5 milyar Yeni Türk Lirası zararla kapatmıştır (TBMM Kamu İktisadi Teşebbüsleri Komisyonu (2010), s. 506). Nitekim, 
08.10.2007 tarihinde Özelleştirme Yüksek Kurulu şirketin satış yöntemiyle bir yıl içinde özelleştirilmesine karar vermiştir. Bu karardan sonra şirketin bazı birimleri kapatılmış bazı mülkleri de satılmıştır, ancak tamamının özelleştirilmesi gerçekleşmeden Özelleştirme Dairesi Başkanlığının 01.06.2009 tarihli yazısı ile Sümerhalı'nın tüm hak ve yükümlülükleriyle malları Sümer Holding'e devredilmiş ve Sümerhalı A.Ş. kapatılmıştır (TBMM Kamu İktisadi Teşebbüsleri Komisyonu (2010), s. 501).

2010 yılı itibariyle rekabet gücündeki azalmadan dolayı Türkiye'de el halı ve kilim imalatının giderek daha da azalacağı, hatta endüstriyel boyutta imalatın kalmayacağı, sadece sanatsal ve kültürel bir unsur olarak üretimin devam edeceği tahmin edilmektedir. Bu çerçevede, ithal bile ediliyorsa, sektörün istihdam ve katma değer yarattığı, ülkeye döviz kazandırdığı, bu nedenle de sektörün önünün açılması gerektiği savunulmaktadır (Bilgin ve Demir, 2010, s. 163). O dönem Türk el halısı sektörü dokumacı bulma sorunu vardır ve bulunsa bile mevcut maliyetler ile rekabet edecek durumda değildir. Özellikle turistlere halı satanlar bir arz problemi içindedir ve ithal el halıları bu açıdan bir can suyu olmuştur (Yıldız, 2021). Bu yıllarda üretimini yurt içinde yapan, istihdam sağlayan ve ürettiği halılarla America's Magnificent Carpets Award gibi önemli ödüller alan rol model olacak firmalar da bulunmaktadır.

El halıcılığı alanında Türkiye için firsat olarak görülen bir iş kolu da eski ve kullanılmış halıların tamir ve bakım işlemlerinin yapılarak tekrar ekonomiye kazandırılmasıdır. Türkiye halıcılık sektörü bu konuda ciddi bir altyapı ve bilgi birikimine sahiptir. Buna rağmen, çeşitli engel ve nedenlerden dolayı Türkiye bu pastadan istenilen payı alamamaktadır. Mevcut potansiyelin kullanılması durumunda, eski halı ve kilim tamir ve bakım işinin önemli bir sektör haline geleceği ve bu sektörün önemli düzeyde istihdam yaratacağl, ülkeye döviz kazandıracağı ifade edilmektedir (Bilgin ve Demir, 2010, s. 123). Bu iş kolu İstanbul' da Sultanahmet, Çemberlitaş ve Nuruosmaniye civarlarında, İzmir Serbest Bölgede, Konya'da, Aksaray ili Sultanhanı Beldesi'nde yapılmaktadır. Eski halıların tamirinin yanı sıra eski halıları ithal edip, tamirini yapıp tekrar satarak yılda 600 milyon dolarlık bir ticaret hacmi oluşturulabileceği ileri sürülmektedir (Bilgin ve Demir, 2010, s. 124).

Türkiye için el halıcılığı alanında gelişen başka bir iş kolu da evlerde âtıl durumda bulunan, kullanılmayan, renkleri ve deseni güncel ev dekorasyonuna uymayan eski el halılarının toplanıp işlenerek yeniden ticari dolașıma sokulmasıdır. Bu iş kolu ilk bașta yıpranmış halıların havlarının kısaltılması, canlı renklerde boyanması, çeșitli şekillerde kesilip yeniden kırkyama gibi birleștirilmesi ve patchwork halı olarak satılmasıyla ortaya çıkmıştır ve bazı çevresel sorunları olmakla birlikte işlemler ileri dönüşüm yani upcycle olarak tanımlanabilir. Bu halılar aşırı talep görerek piyasada yer edinmiş, günümüze geldikçe modaya uygun olarak farklı işlemler geliştirilerek ilerlemiştir. Sektörde yıkamacı olarak adlandırılan işletmeler veya kişiler tarafından yapılan bu işlemler en çok Aksaray Sultanhanı'nda yoğunlaşmakla birlikte Demirci, Uşak, Kayseri, Malatya, Konya, Antalya Döşemealtı ve İstanbul'da yapılmaktadır. Türkiye'de maliyetler nedeniyle el halısı imalatının azalması, 1950'lerden itibaren iç piyasaya dönük on milyonlarca metrekare el halısı imalatının yapılmış olması, bu halıların büyük çoğunluğunun hala evlerde tutulması ve eski halıların toplama maliyetinin yeni üretim maliyetinden ciddi miktarda düşük olması, bu potansiyeli gören, halı tamiri, yıkaması ve imalatı konusunda tecrübeli usta, tüccar ve girişimcileri bu alana yönlendirmiştir. Özellikle Sultanhanı'nda halı tamiratı ile uğraşanların büyük çoğunluğunun yüksek karlılık nedeniyle bu alana kaydığı gözlenmektedir. İlk başları toptancılara çalışan işletme ve atölyeler zamanla online satış kanallarına entegre olarak direkt satışla ihracat da gerçekleştirir duruma gelmişlerdir. Maliyet ve satış arasındaki fark bire beș ile bire on arasında değişmektedir (Aktürk, 2021). Son on yıldır el halısı ticaretinin neredeyse \%90'ını bu tür halıların satılması ile elde edilmektedir. Mevcut stoklarımızın tükenmesi, vintage patchwork, boyalı halı, ağartılmış halı gibi ürünlerimizin modasının yavaş yavaş geçiyor olması nedeni ile bu alanda da ticaretimizin bitmek üzere olduğu söylenebilir (Yıldız, 2021). Bu işle uğraşanlar, eski el halısı ithalatına izin verilmesi ve satış kanallarının denetime bağlanarak açılması durumunda Türkiye'nin jeopolitik konumu ve bu alanda hazır iş gücü potansiyeli nedeniyle çok büyük bir sektör haline gelebileceğini belirtmektedir (Aktürk, 2021, s. 69).

2020'ye gelindikçe, sektör temsilcileri beyanlarında yerli el halısı yeteneğinin kaybedilmemesi ve imalatının canlandırılması için üreticilerin desteklenmesi gerektiğini söylemekte, dokuyucuların SGK ve Gelir Vergisi maliyetlerinin ve ödenecek asgari maaşın yarısının ise devlet tarafından karşılanmasını istemektedir. Kullanılmıș el halısı ithalatındaki yasağın kaldırılmamasının, ithal edilen kullanılmıș halılara katma değer katmak üzere yapılan tamir, yıkama, vb. işlemler konusundaki yetişmiş elemanların istihdamına zarar verdiğinden bahsetmektedirler. Ayrıca, El Halısı İhtisas Gümrüğü'nün sadece Isparta'da olmasının, yüksek depolama, nakliye maliyetleri nedeniyle turizm sektörüne zarar verdiğinden ve el halısı ticaretinin en çok olduğu İstanbul'da da açılması gerektiğinden söz etmektedirler (İstanbul Halı İhracatçıları Birliği [İHİB], 2021, s. 96-114). Temsilciler tarafından el halıcılığının yapılabilmesi için küçük 
baş hayvancılığın önemli olduğu, yün ve iplik üretiminin de teşvik edilmesi gerektiği belirtilmektedir (Aytekin, 2019, s. 41).

Türkiye'de el halısı ticareti yapan firma ve kişilerin en önemli gelir kapılarından birisi turistik merkezlerde turistlere doğrudan yapılan satışlardır. Günümüze gelindikçe, pandemi öncesinde Turistlere yönelik el halısı ticareti yapanlar, son beş yıldır Türkiye'ye gelen turist kalitesinde düşüş yaşandığından, Amerikalı, Avrupalı, Japon ve üst gelir seviyesine sahip turist gelmediğinden, bu nedenle de satış yapamadıklarından şikâyet etmektedirler (Yıldız, 2021).

Pandemi ile beraber, sokağa çıkma yasakları ve kısıtlamalar dolayısı ile el halısı üretimi büyük bir sekteye uğramış, yok denecek kadar azalmıştır. Turistik satışlar hariç, ticarete olumlu yansımaları olmuştur. Online satıș ayağı olan firmalar satıșlarını arttırmıș, olmayan firmalar da online satıșı öğrenmek zorunda kalmıș ve yeni dünya düzenine ayak uydurmak için yeniden yapılanma yoluna gitmişlerdir (Yıldız, 2021).

Türkiye'de el halıcılığının 2010 yılı sonrası durumuna veriler açısından bakıldığında, Türkiye'nin en çok ticaretini yaptığı ithal el halıları için, ithalatın 2010'da 111 milyon dolardan, 2014 yılında 94 milyon dolara hafif bir eğimle azaldığı, bu tarihten itibaren iki sene içerisinde dikey bir düşüş içerisine girip on kat azalarak 9 milyon dolara düştüğü gözlenmektedir; günümüze kadarki dört senede ise grafik neredeyse yatay bir çizgide devam etmektedir ve 2020 yılı verilerine göre 4 milyon dolardır. Türkiye'nin en çok el halısı ithal ettiği ülkelerin bu dönem içinde Hindistan, Çin, Pakistan olduğu gözlenmektedir (Şekil 3).

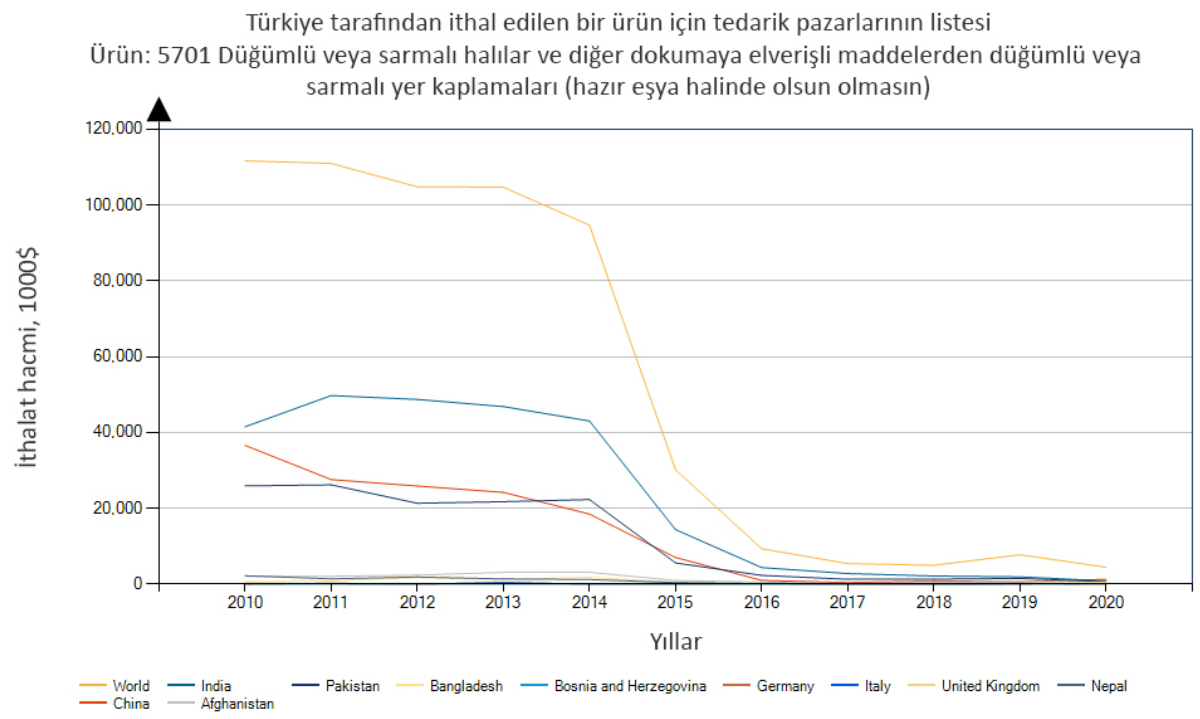

Şekil 3. Türkiye'nin 2010- 2020 arası el halısı ithalatı (www.trademap.org)

El halısındaki ithalat ve ithalata dayalı ihracat 2015 yılında bıçak gibi kesilmiştir. Bu kesilmenin nedeni 18.02.2015 tarihli, 1995'te uygulanmaya başlayan ithalat rejimi kararına çıkarılan ek kararlar ve ithal el halılarına konulan ilave \%50 gümrük vergileridir (İthalat Rejimi Kararına Ek Karar, 2015). Bu karar ile Türkiye’nin halı ithal ettiği Uzak Doğu ve gümrük birliği anlaşması olmadığı üçüncü taraf ülkelerinden gelecek her türlü el dokuması halıya ağır vergi yükleri gelmiştir ve halı tüccarı için bu işin ticari bir cazibesi kalmamıştır.

Türkiye'nin 2010-2020 yılı arası el halısı ihracatının 2011 yılından günümüze her yıl düştüğü görülmektedir. 2010 yılında görülen yükselme 2011 yılına kadar en üst seviye olan 166 milyon doları görmüş, ardından sürekli azalan bir grafikle 2020 yılında 24 milyon dolara inmiştir. 2020 yılında en fazla ihracat gerçekleştirilen il beş ülke Amerika, Japonya, Almanya, Çekoslovakya ve Fransa'dır. (Şekil 4) 20112019 yılları arası için grafik benzer olsa da Ticaret Bakanlığı verileri Trademap verilerinden biraz daha yüksek değerler göstermektedir (Tablo 1). 


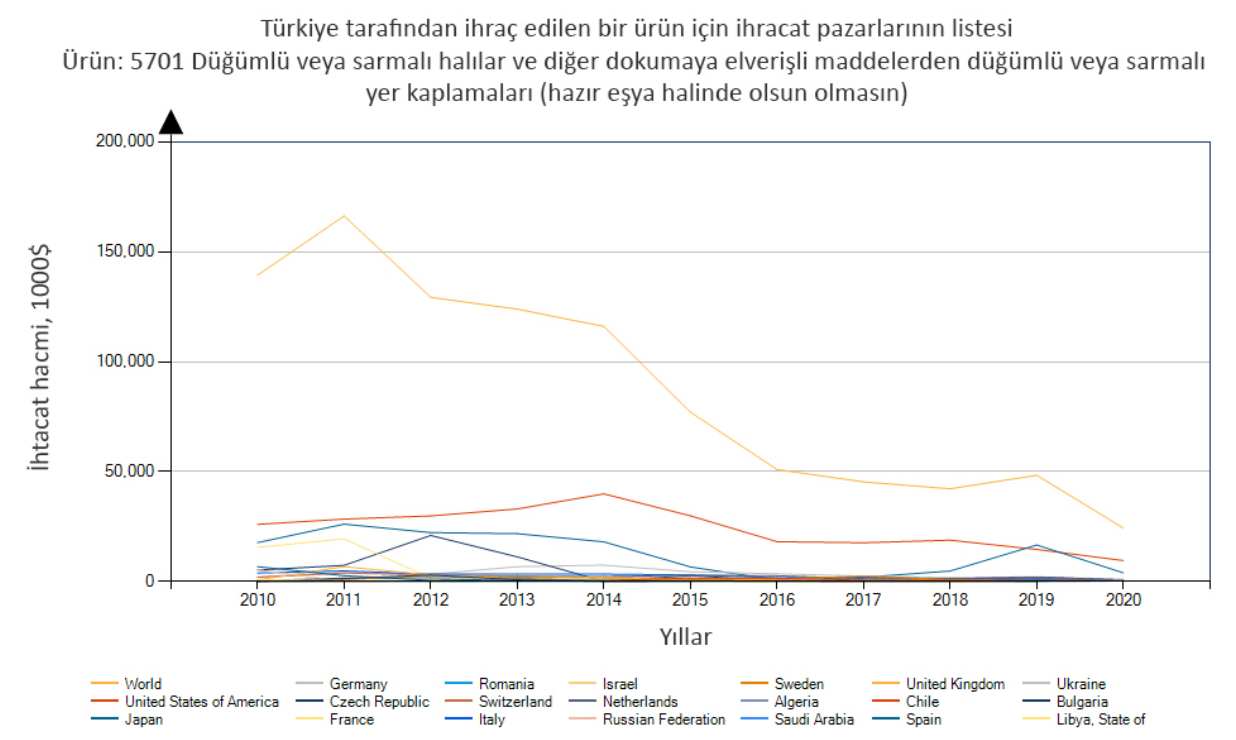

Şekil 4. Türkiye'nin 2010- 2020 arası el halısı ihracatı (www.trademap.org)

Tablo 1. Türkiye'nin 2011-2019 arası el halısı İhracatı (Ticaret Bakanlığı İhracat Genel Müdürlüğü, 2020, s. 11).

\begin{tabular}{|c|c|}
\hline YILLAR & DEĞER (\$) \\
\hline 2011 & 175.532 .255 \\
\hline 2012 & 139.082 .356 \\
\hline 2013 & 132.290 .678 \\
\hline 2014 & 128.388 .994 \\
\hline 2015 & 85.457 .811 \\
\hline 2016 & 59.074 .627 \\
\hline 2017 & 56.289 .638 \\
\hline 2018 & 51.125 .503 \\
\hline 2019 & 55.402 .467 \\
\hline
\end{tabular}

El halısı ihracatı yapan ülkeler sıralamasında Türkiye beşinci sırada yer alırken, onun önünde sırasıyla Hindistan, Pakistan, İran ve Nepal yer almaktadır. Çin Türkiye’den sonra altıncı sıradadır. İlk dört ülkenin dünya el halısı ticaretinde hakimiyetlerinin nedeni;

- İthalatçı ülkelerdeki dağıtım kanallarının, depolarının ve perakende ağının büyük çoğunluğuna sahip olmaları ve buralarda kendi ülkelerinin ürünleri dışında ürünleri satmamaları,

- İşçilik giderlerinin bu ülkelerde oldukça düşük olması nedeniyle ürünleri dünya pazarına düşük fiyatla sunabilmeleri,

- Uzun yıllardır ürünleri için batı pazarlarında oluşturdukları güçlü imaj olarak sıralanmaktadır (Ticaret Bakanlığı İhracat Genel Müdürlüğü, 2020, s. 11).

İHİB'den alınan bilgilere göre, 2021 yll itibariyle Türkiye imalat ve ticaret açısından tarihinin en kötü dönemini yaşamaktadır. İmalat yok denilecek kadar azalmıştır. Türkiye'nin üretim kapasitesini gösteren resmi bir kayıt bulunmamakla birlikte, saha çalışmaları sonucunda resmi destek sağlandığı takdirde 100 bin kişilik iş gücü ve 50 bin tezgâhlık bir üretim kapasitesi olduğu tahmin edilmektedir. Kesin olmamakla birlikte 1000 tezgâh ile 5000 civarı dokuyucunun aktif çalıştığı düşünülmektedir. Devletin el halısı ithalatına getirdiği ek gümrük vergisi nedeni ile ithalat devlet eliyle engellenmiștir. Metre kare başına getirilen \%50 ek gümrük vergisi, hangi gümrük kapısından giriş yaparsa yapsın, halıların Isparta İhtisas Gümrüguüne girişinin mecbur kılınarak extra maliyet ile karşı karşıya bırakılması, el halısı ithalatını imkânsız hale getirmiștir. Tüccarın elinde bulunan yerli ve ithal üretim geçmișten gelen stoklar da bitmek üzere olduğundan şu an büyük bir arz problemi yaşanmaktadır (Yıldız, 2021). 
Online satışın gelişmesi El halısı ticaretini kolaylaştırmıştır. Bu kolaylaşmanın, iç tüketimde değil, ihracatta olumlu katkı sağladığı söylenmektedir. Resmi rakamlara göre 50 milyon dolar olan el halısı ihracatının haricinde online satış kanallarıyla bunun iki katına yakın ihracat yapılmış olduğu düşünülmektedir. Online satışlar genelde ETGB (Elektronik Ticaret Gümrük Beyanamesi) ile ihraç edilmektedir. Normal ihracat olmadığı içi ihracatçı birliklerinin kayıtlarında görünmemektedir; bu da resmi ihracat rakamlarına yansımamasına sebep olmaktadır (Yıldı, 2021).

El halısı daha çok yüksek gelirli, eğitimli, orta ve üstü yaş grubuna hitap eden bir üründür. Gelişmiş ve gelişmekte olan ülkelerde yaşlı nüfusundaki artışın el halısına olan talebi olumlu yönde etkileyeceği düşünülmektedir. İhtiyaçların hızla değişmesi, tüketimi de değiştirmekte, artık kimse halıyı uzun süre kullanılan bir ürün olarak görmemektedir. Halı dekorasyonun temel bir unsuru değil, daha çok bir aksesuar olarak görülmektedir. Hızlı tüketim için makine halısı ve türevlerinin, dijital baskı halıcılığının, el dokuması görünümlü makine halıcılığının giderek gelişeceği, el halıcılığının zamanla etkisini daha da yitirerek butik tarzı üretimlerle tutunmaya çalışacağı tahmin edilmektedir. Burada kişiye özel üretimler, doğal boya ve malzeme ile üretim yapmak, tasarım ve tasarımcı ağırlıklı üretim, planlı atölye üretimi sektörün yaşaması ve daha iyi olması için olmazsa olmaz önerilerdir (Yıldız, 2021).

Türkiye'de el halıcılığında azalma yaşanırken, dünya genelinde de el halıcılığının düşüş trendinde olduğu gözlenmektedir. Trademap verilerine göre Dünya'da toplam el halısı ithalatı her geçen yıl azalmaktadır. (Şekil 5) Dünyada el halıcılığının azalma sebeplerinin başında üretim, ürün ve desen kalitesi açısından gelișen makine üretimi halıcılık ve zemin kaplama sektörü gelmektedir. Makine halıcılığı Türkiye'de öyle ilerlemiştir ki iç piyasada el halısı ve ithal halılara olan hakimiyetinin yanı sıra, ihracatta da parça makine halısı ve tufting halı ihracatı ile 2000 yılında Dünya sıralamasında 6. sıraya yükselmiştir (Bilgin ve Demir, 2008, s. 169).

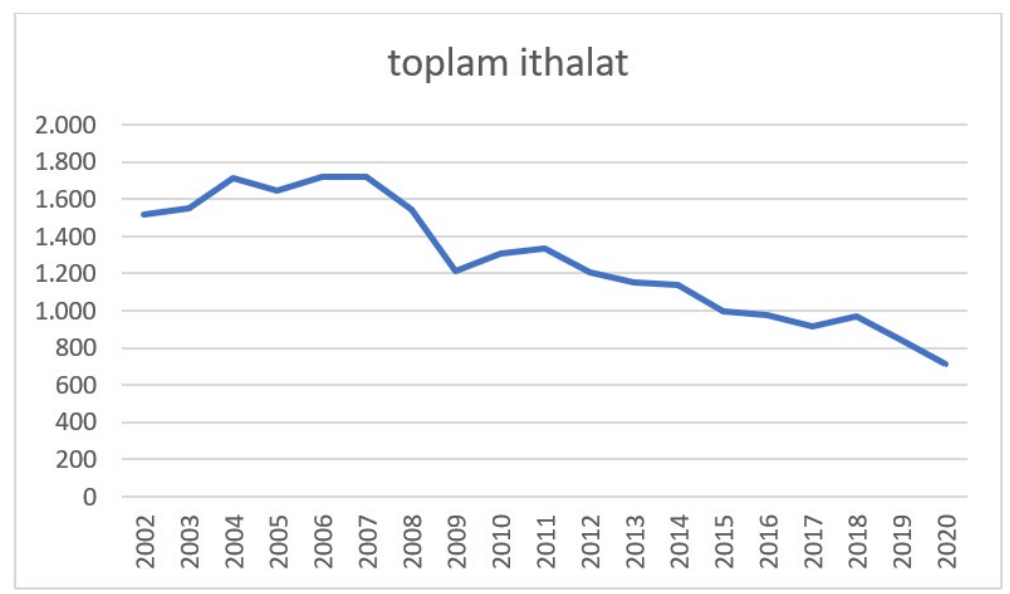

Şekil 5. Dünyada 2002-2020 arası yapılan toplam el halısı ithalatı (x1000\$) (www.trademap.org).

\section{Değerlendirme ve Sonuç}

Milenyum ile dünyada ulaşım ve iletişim teknolojilerinin gelişmesi çok uzakta bulunan insanları birbirine daha önce hiç olmadığı kadar yakınlaştırmış, bu pazarı daha da küreselleştirirken, bölgesel ve küresel ekonomik birliktelikler siyasi bloklaşmaların önüne geçmiştir. Aşırı üretim, tüketiciye seçim yapma avantajı sağlarken, kalite, fiyat ve zamanında teslimat ürünün satış potansiyelini arttıran özellikler olmuştur. Özellikle gelişmiş ülkeler, kaliteli ürün yapan ve güvence veren şirketlerle çalışmayı teşvik eden düzenlemeler getirmişlerdir (DPT, 2001, s. 186). Türkiye'de 1959'da başvurduğu Avrupa Ekonomik Topluluğu (AB) ile bu küresel pazara dahil olma çalışmalarına adım atmış, ardından 1996 yılında imzalanan Gümrük Birliği anlaşması ile Türkiye AB arasında ticaret kapıları tamamen açılmıştır.

Türkiye Gümrük birliği ile Dünyaya açılmış, entegrasyon çalışmalarıyla sosyal ve ekonomik anlamda birçok kazanımlar elde etmiştir. Küreselleşme ile bazı sektörler için Türkiye Avrupa'nın üretim ve tedarik merkezlerinden birine dönüşürken, Uzak Doğu'da fason üretimle birlikte el halıcılığının gelişmesi ve Türkiye'den çok daha ucuza gelen malzeme ve işçilik maliyetleri, yerli el halısı sektörünün karşısına hem tehdit hem de firsat olarak çıkmıştır. 
Yerli el halısı üretimi bu yıllarda daha çok ihracat için yapılmaktadır ve iç piyasadan gelen talep makine halısı sektörünün gelişmesi ile çok azdır ve tüketici eğer el halısı alacaksa daha çok yurt dışından gelen modern tasarımlı, ucuz uzak doğu ürünlerine yönelmektedir. 2000'ler ile İhracata ve turistlere satıș yapan yerli el halısı üreticileri ile tüccarların bir kısmı, Uzak Doğuda halı üretimi veya fason halı ithalatını hem rekabet hem de yüksek karlılık için bir firsat olarak görmüş ve bu kapsamda çalışma yapmaya başlamışlardır. Türkiye ilk başlarda ithalata dayalı olarak yüksek miktarda ihracat yaparken bu tip üretim ve ticaret 2015 yılında devlet eliyle alınan kararlarla bıçak gibi kesilmiștir. Devlet, ithal halıya \%50 ilave gümrük vergisi alma kararı vermiştir ve bu karar sonrası ithalata dayalı el halısı ihracatının anlamlı bir ticari tarafı kalmamıştır. Bunu üzerine, yapılan ithalatın yalnızca Isparta'da bulunan Halı İhtisas Gümrügü üzerinden yapılma zorunluluğu ise maliyetleri, lojistik ve zaman sorunları ile ithalatçı için katlanan sorunlar olmuştur. Türkiye'nin 2016 yılından itibaren 2020'ye Ticaret Bakanlığı verilerine göre yıllık 6-7 milyon dolar civarı el halısı ithalatı vardır. 2016 yılından itibaren 2019'a ihracata bakıldığında 60 milyon dolardan 55 milyon dolara düştüğü görülmektedir. İthalat ile ihracat dengesi açısından, online ticaret yoluyla kayıtlara yansımayan 100 milyon dolarlık el halısı ihracatı da eklendiğinde, yaklaşık 150 milyon doları bulan pozitif bir ticaret vardır. Bu farkın yerli üreticinin ürettiği halılar ile eski el dokuması halıların işlenerek patchwork ve vintage adıyla yeniden satılması ile oluştuğu söylenebilir.

Türkiye bir halı ülkesidir, el halıcığı konusunda yüzlerce yıllık köklü bir geçmişe sahiptir ve bu konuda iddialıdır. Bununla birlikte Türkiye'de el halısı imalatı yıllardır çok düşük bir seviyede ilerlemektedir. Üretim maliyetleri üretim yapmak ve ihracat için oldukça yüksektir. Köyden kente göç, köylerde genç nüfusun çok azalması, emeklilik ve sosyal imkanlar nedeniyle şehirde çalışmayı tercih etmesi, küçük baş hayvancllığın azalması ve buna bağlı yün ve iplik maliyetlerinin yüksekliği el halıcılığını etkileyen faktörlerdir. Ancak sektör el halıcılığındaki becerisini yaratıcllıkla birleştirerek kendine yeni kapılar aralamayı başarmıştır. Bunlar; kullanılmış, atıl durumda, modası geçmiş el halılarının toplanarak işlenmesi ve yeniden katma değerli ürün haline getirilmesidir. Bu işle uğraşanlar, Türkiye'de evlerde bulunan atıl durumdaki halı potansiyeli ile bu işi sürdürebilmektedir, ancak bu kaynak da azalmaktadır. Bununla birlikte sektör temsilcileri yurt dışından eski el halısı ithal ederek bu işin çok daha kapsaml, yüksek ihracat getirisine sahip ve istihdam yaratacak halı tamiratını da kapsayacak şekilde bir sektör olacağını dile getirmektedirler.

Trademap verilerine göre 2001- 2014 arası el halısı ihracat ve ithalatı grafik halinde incelendiğinde ihracatın ithalatla paralel olarak arttığı ancak karlılığın çok fazla olmadığı gözlenmektedir. Ortalama \%20 gibi bir fark vardır. (Tablo 11) Bu rakamlar kayıtlara düșen rakamlardır ve ne kadarının yerli üretim el halıları ve eski el halılarının değerlendirilmesi ile karşılandığı bilinmemektedir.

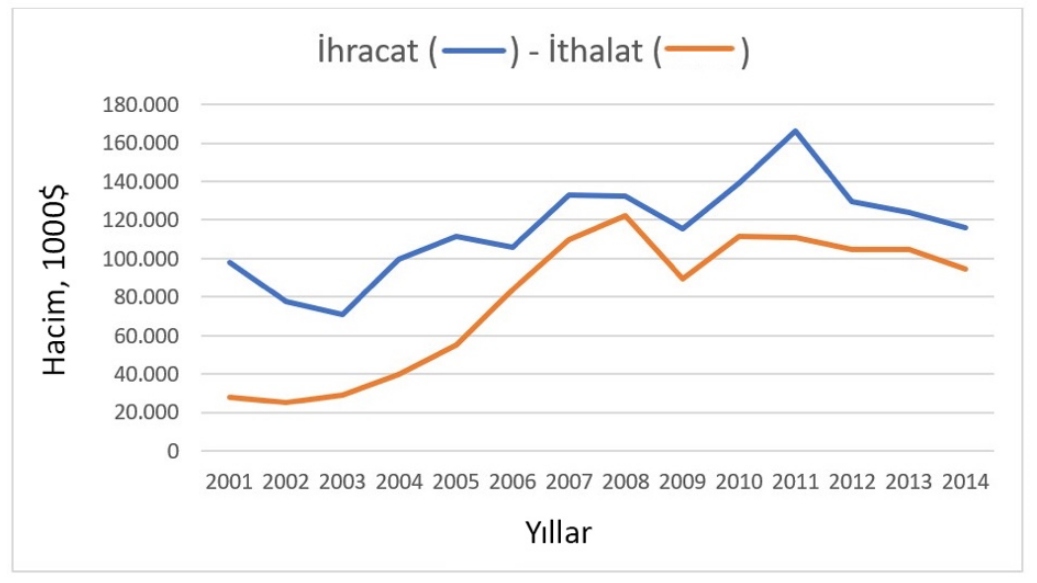

Şekil 6. Türkiye'nin 2001-2014 arası el halısı ihracat ve ithalat grafiği (www.trademap.org).

2001 yılı kalkınma planında Türkiye'nin 1,5 milyar dolar ihracatının bulunduğu ve bunun 1,15 milyar dolarının turistlere satıştan ve geri kalanının direkt ihracatla yapıldığı bilgisi verilmesi, eğer veriler doğruysa Türkiye'nin Dünya ticaret verilerine yansımayan oldukça yüklü miktarda bir el halısı ticaret hacmi olduğunu göstermektedir. Daha sonraki yıllardaki hem Ticaret Bakanlığı hem de Trademap verileri bu bilgileri yalanlar nitelikte olmakla birlikte, el halıcllğ̆ için üretim, iç ve dış ticaret hacmini gerçek değerlerde gösterir bir kayda erişmek oldukça güçtür. Günümüze geldikçe gelişen online satış kanallarından yapılan el halısı ihracatının kayıtlara yansımaması ve kayıt dışı olarak yapılan halı ticareti nedeniyle el halısı sektörünün ticari durumu hakkında kesin bir veriye ulaşmak daha da zorlaşmaktadır. 
Türkiye'de 2021 yılı itibariyle büyük çaplı el halısı üretimini bittiği bir gerçektir. El halısı sektörü temsilcileri, yerel el halıcılığının unutulmaması için maaş, sosyal güvenlik ve emeklilik ödemeleri için devlet desteğinin olması, küçük baş hayvancılığa ve iplik üretimine önem verilmesi gerektiğini söylerken; üreticinin ayakta kalması için, kişiye özel üretim, doğal boya ve malzeme ile üretim, tasarım ve tasarımcı ağırlıklı üretim, planlı atölye üretimi yapması gerektiğini tavsiye etmektedir. Üretimin haricinde eski el dokuma halıların tamir ve bakımı ile bu halılar üzerinde yapılan ișlemler sonrası satıștan sektörün büyük beklentisi bulunmaktadır. Bunun için eski ve yeni el dokuması halılara ithalat serbestisi getirilmesi, Halı İhtisas Gümrüklerinin İstanbul başta başka illerde de açılması, bu ticaretin önündeki engellerin kalkmasındaki en önemli öncelikler olarak görülmektedir.

\section{Kaynakça}

Aktürk, D. F. (2021). El dokuması eski halıların işlenerek yeniden değerlendirilmesi. [Yüksek Lisans Tezi, Dokuz Eylül Üniversitesi, Güzel Sanatlar Enstitüsü]

Aytekin, H. (2019). Halı ve kiim, sanayi ürünü değil, el sanatı olarak değerlendirilmeli. İTKİB Hedef, Eylül, 310-312.

Bilgin, M. H. ve Demir, E. (2008). Türkiye el halıcılığı sektör araştırması. İstanbul Ticaret Odası Yayınları, Yayın NO: 2008-8, 2, İstanbul.

Bilgin, M. H. ve Demir, E. (2010). Türkiye el halıcılı̆̆ı sektörü: Eski halı tamir sektörü ve ihtisas gümrüğü uygulamaları. İTO İstanbul Ticaret Odası Yayınları, Yayın No: 2010-46, İstanbul.

Devlet Planlama Teşkilatı (2001). Sekizinci beş yıllık kalkınma planı 2001-2005, tekstil ve giyim sanayii özel ihtisas komisyonu raporu, dokuma ve giyim sanayi özel ihtisas komisyonu halı ve yer kaplamaları alt komisyon raporu. DPT: 2549- ÖIK: 565, Ankara.

Güngör, T. (2010, 13 Temmuz), İzin veriniz de el halısını da üretecek yerde ithal etmeyelim. Dünya. https://www.dunya.com/kose-yazisi/izin-veriniz-de-el-halisini-da-uretecek-yerde-ithaletmeyelim/7441

İstanbul Halı İhracatçıları Birliği. (2021). IHİB 2019-2020 yılları faaliyet raporu. İHİB Yayını.

İthalat Rejimi Kararına Ek Karar. (2015, 19 Şubat), Verginet. https://www.verginet.net/Dokumanlar/2015/Ithalat-Rejimi-Kararina-Ek-Karar-Hali-Ithalati2015-02-18.pdf

Özdemir, Y. ve Güner Koç, A. (2016). Avrupa Birliği (AB) Gümrük Birliği’nin Türkiye ekonomisine etkileri. Ufuk Üniversitesi Sosyal Bilimler Enstitüsü Dergisi, 9: 45-59.

Öztürk, B. (2021). Cumhuriyet Türkiye’si Halıcılığı-II: 1980-2000 Yılları Arası. Arış, No. 18, 2021, $122-140$.

TBMM Kamu İktisadi Teşebbüsleri Komisyonu. (2010). Kamu İktisadi Teşebbüslerin 2008 yılı denetimine ilişkin komisyon raporu. TBMM Basımevi, Ankara.

Ticaret Bakanlığı İhracat Genel Müdürlüğü. (2020). Halı sektör raporu. Ticaret Bakanlı̆̆l.

Türkiye'de el halısı üretimi ve ticaretine ilişkin alınan yazılı bilgi (Yıldız, N., İHİB Denetim Kurulu Üyesi, 2021, 20 Kasim). 